\title{
Value of Intraoperative Transesophageal Echocardiography during tetralogy of Fallot repair
}

\author{
Borodinova 0.
}

\author{
GI «The scientific-practical children’s cardiac center» (Kyiv)
}

\begin{abstract}
This study was performed to define a value of intraoperative transesophageal echocardiography (ITEE) during tetralogy of Fallot (ToF) repair.

Methods. Intraoperatively 64 patients with ToF were examined by TEE before and after cardiopulmonary bypass (CPB).

Results. All preoperative diagnosis were confirmed by ITEE, except two cases when ITEE excluded diagnosis of PA branches' stenosis and one case when additional muscular ventricular septal defect was detected. Was revealed a strong correlation of PV annulus Z-score diameter by ITEE with intraoperative data $(r=0,802 ; \mathrm{p}<0.00001)$. Significant RVOTO was detected by ITEE in two patients $(3,1 \%)$ and three patients $(4,7 \%)$ underwent a reoperation on pulmonary branches due to ITEE data.
\end{abstract}

Conclusions. ITEE imaging is a valuable, safe and accurate tool for anatomical, hemodynamic, and functional assessment during ToF repair.

Key words: tetralogy of Fallot, intraoperative transesophageal echocardiography.

Transesophageal echocardiography is currently gaining increasing popularity as a means of continuous cardiac imaging during open heart operations [1,2]. Its ability to monitor ventricular's function, valves' abnormalities and to assess the adequacy of surgical repair is well defined [3, 4]. TEE is suitable for intraoperative application and its indications are extended to all situations in which detection of abnormalities is needed. For this reason patients with congenital heart defects should benefit most from the intraoperative use of TEE. Experience of ITEE during ToF repair, however, is limited mainly because of limited availability of TEE and to the fact that adequacy of RVOT reconstruction during ToF repair is based on measuring of intracardiac pressures and sizing the RVOT with Hegar dilators, whereas ITEE data is used only as an additional tool [5].

We present our experience with two- dimensional color Doppler TEE used intraoperatively in a series of patients undergoing ToF repair in Ukrainian Children's Cardiac Center, Kyiv, Ukraine. This report focuses on the technical feasibility of 2-D TEE and its potential advantages for the cardiac surgeon.

Material and Methods. Between July 2016 and July 2018, 64 patients with ToF underwent total correction. All patients were imaged by a Philips iE33 echocardiography machine for TEE with a pediatric biplane transducer probe used in patients of less than $15 \mathrm{~kg}$ body weight (Philips Ultrasound, Bothell, WA). TEE was performed before CPB in order to reveal venricular sepyal defect (VSD), additional morphological features of the right ventricular outflow tract
(RVOT), the RVOT obstruction level and the pulmonary artery annulus and the branches size.

Insertion of the probe was performed in the anesthetized patient after endotracheal intubation, either blindly or under direct visualization of the pharynx with the neck moderately flexed. Advancement of the generously lubricated probe was accomplished very gently in the flexible mode with the control unlocked. Transesophageal echocardiographic monitoring was started before skin incision and continued throughout the entire procedure, being temporarily suspended during cardiopulmonary bypass to minimize the risk of esophageal damage due to probe heating and temperature gradient during this period. At the end of each procedure, just before transfer of the patient from the operating room to the intensive care unit, the probe was removed.

The quality of 2-D TEE was considered satisfactory in all cases and there were no problems with probe insertion.

For evaluation of the VSD in terms of location, size, and margins we used the following TEE views: midesophageal 4-chamber (ME $4 \mathrm{Ch}$, Figure 1), ME long-axis (ME LAX, Figure 2), ME AV shortaxis (ME AV SAX, Figure 3), ME right ventricular inflow-outflow (ME RV in-out, Figure 4). Color Doppler interrogation allowed to analyse the direction of flow across the VSD and to evaluate the potential additional shunts (Figure 4).

To evaluate the anatomy of the RVOT we used ME RV in-out (Figure 4), to interrogate the main and branch pulmonary arteries the preferred planes were the ME ascending aortic SAX and upper-esophageal aortic arch SAX views (Figure 6). Doppler techniques were applied to evaluate 


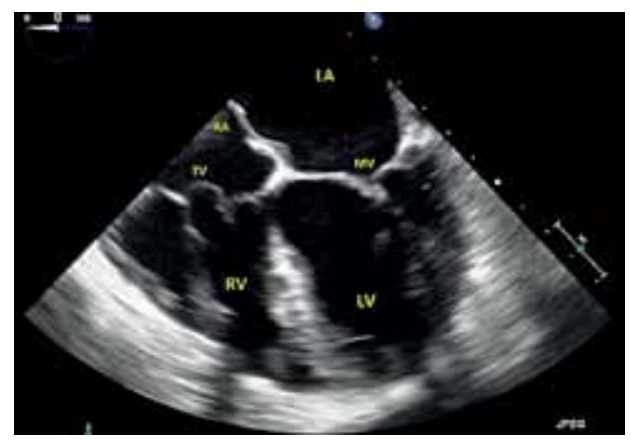

Figure 1. Midesophageal 4-chamber (ME 4 Ch) demonstrates two ventricles and atrio-ventricular valves

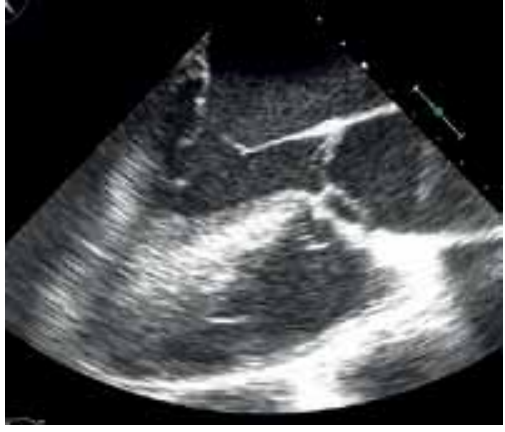

Figure 2. ME long-axis (ME LAX) shows interventricular septum and long axis of aotic valve

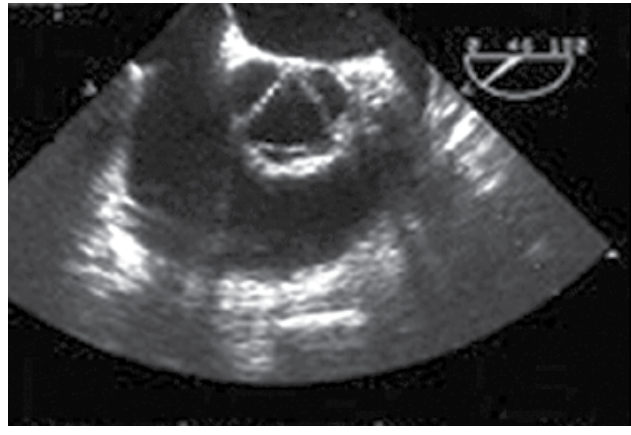

Figure 3. ME AV short axis view (ME AV SAX)
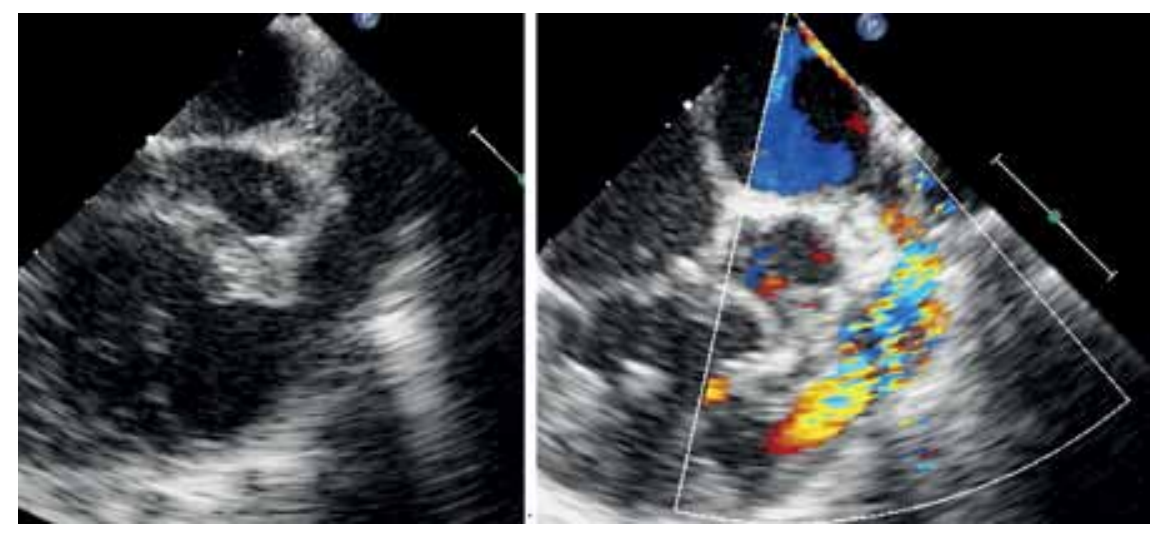

Figure 4. ME right ventricular inflow-outflow (ME RV in-out) demonstrates tricispid valve, right ventricle and RVOT (2D and Collor Doppler)

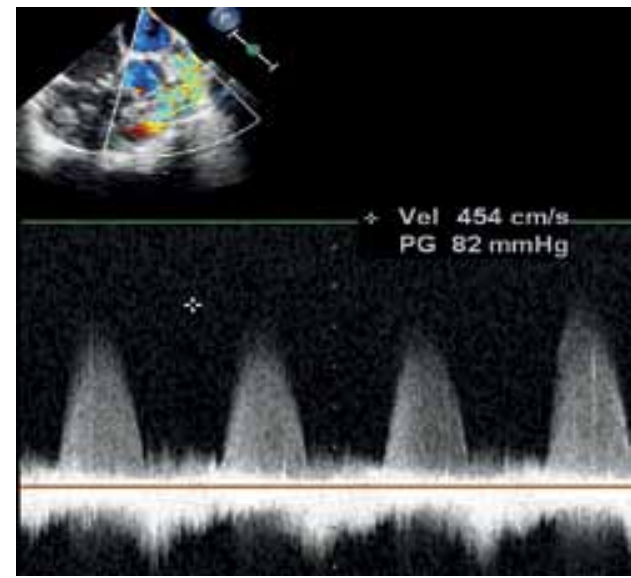

Figure 5. CW Doppler demonstrates the residual gradient on RVOT after ToF repair

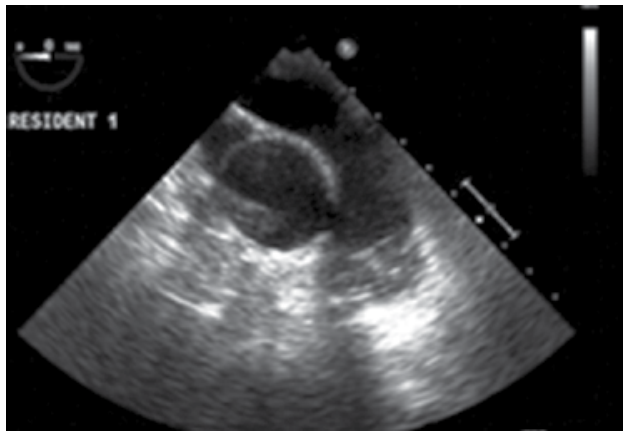

Figure 6. ME ascending aortic SAX and upper-esophageal aortic arch SAX views demonstrate pulmonary trunk and pulmonary branches

the nature, location, and severity of the RVOT obstruction. Color and Pulsed-wave Doppler assisted in localizing the obstruction. Continuous-wave Doppler was used to evaluate the severity of the RVOT obstruction by application of the modified Bernoulli equation (4V2= P1-P2) (Figure 5). A peak jet velocity higher than $4 \mathrm{~m} / \mathrm{s}$ (estimated gradient exceeding $64 \mathrm{~mm} \mathrm{Hg}$ ) was considered to be severe in nature.
The aortic root was best evaluated by 2D and color flow mapping across the AV and LVOT in a number of views, including the ME AV SAX and ME AV LAX.

TEE was also valuable to evaluate for the presence of intracardiac air and monitor the adequacy of cardiac deairing, using the ME $4 \mathrm{Ch}$ and ME LAX views.

After CPB ITEE allowed to evaluate the surgical intervention and to assess a hemodynamically significant residual defects that may need revision. Additional contributions of TEE in the postbypass period include guidance of the surgical revision if indicated, influences on anesthetic and hemodynamic management by facilitating the choice of appropriate pharmacological agents/other therapies, and planning and optimization of postoperative care. After CPB the following parameters were evaluated during ITEE: 1) right and left ventricular function; 2) presence of tricuspid regurgitation; 3) presence of any residual VSD; 4) presence of residual RVOT obstruction; 5) presence of pulmonary valve regurgitation and 6) presence of residual PA branches stenosis.

Furthermore, in the patient with tetralogy of Fallot TEE helped to monitor the effect of vasodilator therapy in weaning 


\section{Table 1}

Concomitant cardiac defects

\begin{tabular}{|c|c|c|}
\hline Concomitant cardiac defects & $\mathbf{n}$ & $\%$ of all patients \\
\hline Right Aortic Arch & 12 & 19 \\
\hline Patent ductus arteriosus & 8 & 12,5 \\
\hline Pulmonary artery branches stenosis & 10 & 15,6 \\
\hline $\begin{array}{l}\text { Left superior vena cava to coronary } \\
\text { sinus }\end{array}$ & 3 & 4,7 \\
\hline Vascular ring & 3 & 4,7 \\
\hline VSD multiple minimal & 2 & 3 \\
\hline $\begin{array}{l}\text { Anomalous origin of the left } \\
\text { coronary artery from right coronary } \\
\text { artery }\end{array}$ & 1 & 1,5 \\
\hline $\begin{array}{l}\text { Left superior vena cava to left } \\
\text { atrium }\end{array}$ & 1 & 1,5 \\
\hline Right ventricle rhabdomioma & 1 & 1,5 \\
\hline Situs inversus with dextrocardia & 1 & 1,5 \\
\hline
\end{tabular}

the patient from cardiopulmonary bypass. Variations of cardiac function due to hypovolemia or hypocontractility were instantaneously recognized by TEE in all patients, allowing us to select the most proper treatment in each situation.

Results. During the interval of July, 2016 to July, 2018, 2D TEE was used intraoperatively in 64 children undergoing ToF repair. There were 25 female and 39 male patients, with median age at surgery of 7,0 months (within the range 0,9-41,7 months). With PV preservation were operated 48 patients $(75 \%)$ and with transannular patch -16 patients (25\%). By the echocardiographic examination, $42(67,7 \%)$ of 64 patients, were diagnosed with concomitant nonsignificant cardiac defects, the spectrum of which is presented in Table 1.

All preoperative diagnosis were confirmed by ITEE, except two cases when ITEE excluded diagnosis of PA branches' stenosis, that was proved by direct Hegar measurements and one case when additional muscular ventricular septal defect was detected. PV diameter was feasible by ITEE in all patients before CPB. Was revealed a strong correlation of $\mathrm{PV}$ annulus $\mathrm{Z}$-score diameter by ITEE with intraoperative data $(r=0,802 ; p<0.00001)$. Significant RVOTO was detected intraoperativly in two patients $(3,1 \%)$ patients. These two patients had immediate surgical revisions in operating room due to severe RVOTO according to pressures and ITEE data. The first patient had a subpulmonary stenosis with a maximum RVOT gradient of $80 \mathrm{mmHg}$ by ITEE, Prv/Plv ratio 1,1 , intraoperative $\mathrm{PV} \mathrm{Z}$-score value of 0,4 . The second patient had a subpulmonary stenosis with a maximum gradient of $27 \mathrm{mmHg}$ by ITEE, Prv/Plv ratio 0,73 , intraoperative $\mathrm{PVZ}$-score value of 0,5 . In both cases we returned to the $\mathrm{CPB}$ and realized a more aggressive muscular resection without transannular patch.

Three patients $(4,7 \%)$ underwent a reoperation due to intraoperative TEE data of significant pulmonary branches stenosis. Two patients had satisfactory RV/LV pressures and direct measurements after CPB and hadn't ITEE signs of significant pulmonary branches stenosis, nevertheless they have progressed before discharge. We believe a transannular patch may deform the pulmonary branches due to the absence of closing mechanism in pulmonary valve position, severe pulmonary regurgitation and RVOT aneurysm formation.

The residual ventricular septal defects were detected intraoperatively after CPB in 10 patients $(15,6 \%)$ which were nonsignificant and did not require immediate surgical revision.

After tetralogy of Fallot repair mean intraoperative gradient through the RVOT measured by TEE was $23,6 \pm 13,6$ $\mathrm{mmHg}$ that correlated good with mean intraoperative gradient $(21,5 \pm 10,1(\mathrm{mmHg}))$ measured by direct measurements and with data at discharge transthoracic echocardiography $(28,7 \pm 15,1(\mathrm{mmHg})) \quad(\mathrm{r}=0,628$ and $\mathrm{r}=0,5186$, respectivly). Intraoperatively PV insufficiency was seen in 33 patients $(51,5 \%)$ with mild degree in 13 patient, moderate - in 9 patients and severe - in 1 patient. At discharge PV insufficiency was revealed in 55 patients $(85,9 \%)$ with mild degree in 30 patient, moderate - in 8 patients and severe in 6 patients.

Discussion. The results of this study show the potential advantages of the intraoperative use of TEE during ToF repair. Transoesophageal echocardiograms are important adjunctive tests in patients with tetralogy of Fallot, with the images being collected using sweeps similar to those providing transthoracic echocardiograms.

Intraoperative transoesophageal echocardiograms are routinely performed in patients undergoing cardiac surgical repair of tetralogy of Fallot [1, 2]. The most common indications are during open heart surgery and when there are unsatisfactory transthoracic images. It helps in cardiac visualization when transthoracic images are not obtainable or are deemed inadequate. Preoperatively, these images aid in the confirmation of the intracardiac anatomy. They should not be considered the initial diagnostic test, as delineation of the intracardiac anatomy should be completed usually by transthoracic echocardiography, prior to entering the operating suite. The postoperative TEE echocardiograms are used to confirm successful surgical repair. They should exclude residual atrial or ventricular septal defects, residual obstruction in the right ventricular outflow tract, assess the degree of pulmonary or tricuspid regurgitation, and evaluate the right and left ventricular function following the repair. A routine, systematic, approach to TEE will allow the clinician to evaluate effectively all the intracardiac anatomy $[4,6]$. Moreover, ITEE permits uninterrupted monitoring of cardiac performance throughout the surgical procedure and therefore evaluation of the effectiveness of any inotropic or vasoactive drug administered [7]. The advantage of ITEE over intraoperative epicardial 2-D echocardiography is poor surface con- 
tact and heart compression with consequent arrhythmias are avoided and temporary discontinuation of the operation is not required.

Some of the contraindications for transoesophageal echocardiography include oesophageal abnormalities or prior oesophageal surgery, active gastrointestinal bleeding or coagulopathy, respiratory decompensation or inadequate control of the airway, or abnormalities of the cervical spine or pharynx [8].

Conclusions. ITEE imaging is a valuable, safe, feasible, and accurate tool for anatomical, hemodynamic, and functional assessment in patients with $\mathrm{ToF}$ during surgical repair. TEE offers the advantage of permitting visualization of the operative procedure in real time and provides guidance for the surgeon in making decisions inside the operating room.

\section{References}

1. Ayres, NA., Miller-Hance, W., Fyfe DA, Stevenson JG, Sahn DJ, Young LT, et al. Indications and guidelines for performance of transesophageal echocardiography in the patient with pediatric acquired or congenital heart disease. A report from the task force of the pediatric council of the American society of echocardiography. Journal of American Society of Echocardiography. 2005; 18, 1; 91-98.

2. Hahn RT, Abraham T, Adams MS, Bruce CJ, Glas KE, Lang RM et al. Guidelines for performing a comprehensive transesophageal echocardiographic examination: recommendations from the American Society of Echocardiography and the Society of Cardiovascular Anesthesiologists. J Am Soc Echocardiogr. 2013; 26:921.

3. Guzeltas A, Ozyilmaz I, Tanidir C, Odemis E, Tola HT, Ergul Y, et al. The significance of transesophageal echocardiography in assessing congenital heart disease: our experience. Congenital Heart Disease. 2014; 9: 300-306.

4. PuriGD, RajR, TacyTA.Transesophagealechocardiography for tetralogy of Fallot repair: What a perioperative physician need to know? Journal of Perioperative Echocardiography. July-December 2014;2(2):51-57.

5. Fraser CD, McKenzie ED, Cooley DA. Tetralogy of Fallot: surgical management individualized to the patient. Ann Thorac Surg. 71 (2001); 1556-1563.

6. Soo-Jin Kim, Sin-Ae Park, Jinyoung Song, Woo Sub Shim, Eun Young Choi, Sang Yoon Lee. The Role of Transesophageal Echocardiography During Surgery for Patients With Tetralogy of Fallot. Pediatric Cardiology. Feb 2013;34, 2; 240-244.

7. Shen-Kou Tsai. The role of transesophageal echocardiography in clinical use Journal of the Chinese Medical Association.76 (2013); 661-672.

8. Garg R, Murthy K, Rao S, Muralidhar K. Intra-operative transesophageal echocardiography in congenital heart disease. Ann Card Anaesth. 2009;12:166.

\section{Значення інтраопераційної черезстравохідної ехокардіографії при корекції тетради Фалло}

\section{Бородінова О.С.}

ДУ «Науково-практичний медичний центр дитячої кардіології та кардіохірургії МОЗ України» (Київ)

Дослідження було проведено для визначення цінності внутрішньоопераційної черезстравохідної ехокардіографії (ITEЕ) під час корекції тетради Фалло (ТoF).

Методи. У період з липня 2016 року по липень 2018 року 64 пацієнти були радикально прооперовані з приводу тетроди Фалло. Всі пацієнти були обстежені за допомогою ITEЕ до та після штучного кровообігу, а також за допомогою прямих вимірювань серцевих структур та градієнтів тиску. Інтраопераційні ехокардіографічні дані порівнювалися з інтраопераційними градієнтами та ехокардіографічними даними при виписці.

Результати. Було прооперовано 25 пацієнтів жіночої статі та 39 пацієнтів чоловічої статі, середній вік яких склав 7,0 місяців (у межах від 0,9 до 41,7 місяців). Із збереженням клапана легеневої артерії було прооперовано 48 пацієнтів (75\%), із трансанулярною пластикою - 16 пацієнтів (25\%). Всі передопераційні діагнози був підтверджені методом ITEE, за винятком двох випадків, коли ITEЕ виключив діагноз стенозу гілок легеневої артерії, що було підтверджено безпосереднім вимірюванням за допомогою розширювачів Hegar, та одного випадку, коли був виявлений додатковий м'язовий дефект міжшлуночкової перегородки. Було встановлено сильний кореляційний зв'язок Z-score діаметру клапана легеневої артерії, виміряного за допомогою TEE, з інтраопераційними даними $(\mathrm{r}=0,802 ; \mathrm{p}<0,00001)$. Методом ITEE виявили значний RVOT у двох пацієнтів $(3,1 \%)$, які потребували негайної хірургічної корекції в операційній залі. Три пацієнти $(4,7 \%)$ потребували повторно операції через інтраопераційні ТЕЕ дані про важкі стенози гілок легеневої артерії, які були повторно відкориговані без вї̈зду з операційної. Було виявлено помірний кореляційний зв 'язок інтраопераційного градієнта через RVOT, виміряного за допомогою TEE, з інтраопераційним градієнтом при прямому вимірюванні та з трансторакальними ехокардіографічними

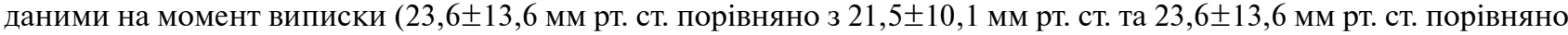
з $28,7 \pm 15,1$ мм рт. ст.; $\mathrm{r}=0,628$ і r $=0,5186$ відповідно).

Висновки. ITEЕ $є$ цінним, безпечним і точним інструментом для анатомічної, гемодинамічної та функціональної оцінки пацієнтів під час хірургічноі корекціі тетради Фалло. ТЕЕ пропонує переваги, що дозволяють візуалізувати роботу серця під час операції в режимі реального часу та допомагають хірургу у прийнятті рішень безпосередньо в операційній.

Ключові слова: тетрада Фалло, радикальна корекція, інтраопераційна черезстравохідна ехокардіографія. 